\title{
EFEKTIFITAS BERBAGAI VARIASI KONSENTRASI BEKATUL TERHADAP PERTUMBUHAN Candida albicans
}

\author{
Effectiveness of Various Variations in Brand Concentration on the Growth of Candida \\ albicans
}

Nurlia Naim ${ }^{1}$, Magfirah Arifuddin ${ }^{2}$, Hurustiaty $^{3}$, Zulfikar Ali Hasan ${ }^{4}$

${ }^{1,3,4}$ Jurusan Analis Kesehatan Poltekkes Kemenkes Makassar

${ }^{2}$ Prodi Sarjana Terapan Teknologi Laboratorium Medis Poltekkes Kemenkes Makassar

Koresponden : nurlianaim0416@gmail.com/081342466491

\begin{abstract}
Skin fungal infections are quite common in Indonesia, one of which is caused by Candida albicans namely candidiasis. This disease can be examined macroscopically with SDA media whose prices are quite expensive, hygroscopic and not obtained anywhere so that an alternative medium needs to be made using bran. This study aims to determine the effectiveness of various variations in bran concentration as an alternative medium to the growth of Candida albicans. This type of research is laboratory experimental research. This research was conducted on May 5, 2019 to May 23, 2019 at the Microbiology Laboratory of the Makassar Center for Health Laboratory. The object of this study was bran with a concentration of 5\%, 10\%, and $15 \%$ which was tested against Candida albicans as the research subject. Media SDA (Sabouraud Dextrose Agar) was used as a positive control for the growth of Candida albicans. The results obtained showed that bran can be used as an alternative medium for the growth of Candida albicans at a minimum concentration of 5\% and effective media were obtained at concentrations of $10 \%$ to $15 \%$, which were macroscopically almost the same even more than colonies on SDA media. It is recommended that in future studies be able to test the growth of fungi in bran media of diverse species.
\end{abstract}

Keywords : Bran and Candida albicans

\begin{abstract}
ABSTRAK
Infeksi jamur kulit cukup banyak ditemukan di Indonesia, salah satunya disebabkan oleh Candida albicans yaitu kandidiasis.Penyakit ini dapat diperiksa secara makroskopis dengan media SDA yang harganya cukup mahal, higroskopis dan tidak diperoleh sembarang tempat sehingga perlu dibuat media alternatif salah satunya yaitu menggunakan bekatul. Penelitian ini bertujuan untuk mengetahui efektivitas berbagai variasi konsentrasi bekatul sebagai media alternatif terhadap pertumbuhan Candida albicans. Jenis penelitian ini adalah penelitian eksperimen laboratorik. Penelitian ini dilakukan pada tanggal 5 Mei 2019 sampai 23 Mei 2019 di Laboratorium Mikrobiologi Balai Besar Laboratorium Kesehatan Makassar. Obyek penelitian ini adalah bekatul dengan konsentrasi 5\%, 10\%, dan 15\% yang diujikan terhadap Candida albicans
\end{abstract}

Vol. 11 No. 1, Juni 2020 
sebagai subyek penelitian. Media SDA (Sabouraud Dextrose Agar) digunakan sebagai control positif terhadap pertumbuhan Candida albicans. Hasil penelitian yang dieroleh mennunjukkan bahwa bekatul dapat digunakan sebgai media alternatif terhadap pertumbuhan Candida albicans pada konsentrasi minimal 5\% sedangkan konsentrasi media bekatul yang efektif didapatkan pada konsentrasi $10 \%$ sampai dengan $15 \%$ yaitu secara makroskopik hampir sama bahkan lebih dari koloni pada media SDA. Disarankan agar pada penelitian selanjutnya dapat menguji pertumbuhan jamur pada media bekatul dari spesies yang beragam

Kata kunci : Bekatu dan Candida albicans

\section{PENDAHULUAN}

Proses penggilingan gabah padi menghasilkan beras sebanyak 60-65\%. Dalam setiap proses produksi tidak akan terlepas dari sebuah hasil samping. Hasil samping tersebut sebagian besar dapat dimanfaatkan dan ada pula yang tidak. Demikian juga dalam proses pengolahan gabah menjadi beras menghasilkan hasil samping berupa limbah. Limbah yang paling kasar adalah sekam dan yang agak halus adalah dedak, sedangkan yang paling halus adalah bekatul.

Produksi bekatul halus dari penggilingan padi di Indonesia mencapai 4-6 juta ton per tahun. Menurut catatan Pusat Penelitian dan Pengembangan Pertanian Bogor, kegiatan penyosohan beras bisa mengikis 7,5\% dari bobot beras awal. Tujuh setengah persen tersebut berupa bekatul yang memiliki kadar selulosa dan hemiselulosa yang paling tinggi dibandingkan dengan berasnya itu sendiri (Nursalim dan Razali, 2007). Di samping itu, bekatul dapat dipakai sebagai bahan bakar dan bahan baku industri farmasi. Dengan penemuan Lembaga Eijkman Indonesia, bekatul dapat diekstrak untuk sumber vitamin B. Asam fitat dalam bekatul dapat dipakai sebagai bahan pengkelat dalam berbagai industri, baik sebagai antioksidan, anti pengkaratan, dan penjernihan air (Tangendjaja 1991 dalam Dewi et al, 2005).

Sejak dulu bekatul hanya dikenal masyarakat sebagai bahan pakan ternak dengan mutu yang rendah. Padahal kandungan zat gizi atau nutrisi yang dimiliki oleh bekatul cukup baik dimanfaatkan untuk produk yang bermanfaat bagi kesehatan. Bekatul mempunyai sumber karbon dan nitrogen lebih kompleks dibanding media lain. Bekatul mempunyai kandungan vitamin B. Vitamin B tertentu yang terdapat dalam medium merupakan faktor penting untuk pertumbuhan jamur. Beberapa penelitian menunjukkan bahwa bekatul dapat dimanfaatkan sebagai media untuk pertumbuhan jamur penghasil enzim, seperti Aspergillus niger, Rhizopus sp, dan Mucor sp. Dengan kata lain, bekatul dapat digunakan sebagai substrat untuk menghasilkan enzim. Jenis enzim yang dihasilkan tergantung pada media dan kondisi lingkungan (Satyawiharja 1984 dalam Dewi et al, 2005).

Selain kandungan bekatul yang memiliki kualitas yang cukup baik dan memiliki potensi yang dapat dijadikan sebagai media alternatif pertumbuhan jamur, bekatul juga sangat mudah ditemukan di lingkungan masyarakat khususnya masyarakat pedesaan, sehingga akan sangat menguntungkan 
apabila dapat dimanfaatkan sebagai media alternatif pengganti SDA (Sabouraud Dextrose Agar).

Pemanfaatan bekatul sebagai media pertumbuhan mikroorganisme didasarkan pada kandungan komponenkomponen nutrisi yang dibutuhkan mikroorganisme. Bekatul mengandung karbohidrat tinggi, protein, lemak, vitamin, dan serat kasar (Houston 1972 dalam Dewi et al, 2005).

SDA adalah media yang umum untuk pertumbuhan jamur di laboratorium karena memiliki $\mathrm{pH}$ yang rendah $(5,6 \pm 2)$ sehingga menghambat pertumbuhan bakteri yang membutuhkan lingkungan yang netral dengan $\mathrm{pH} 7,0$, dan suhu optimum untuk pertumbuhan antara $25-30{ }^{\circ} \mathrm{C}$. Tingginya harga media SDA instan yang mencapai Rp.680.000,- hingga Rp.1.200.000,- setiap 500 g, sedangkan melimpahnya sumber alam yang dapat digunakan sebagai media pertumbuhan mikroorganisme mendorong peneliti untuk menemukan media alternatif dari bahan yang mudah didapat serta harganya relatif murah.

Berdasarkan penelitian sebelumnya mengenai Bekatul sebagai Media Pertumbuhan Jamur Aspergillus $s p$ diperoleh hasil bahwa bekatul dapat dimanfaatkan sebagai media pertumbuhan jamur Aspergillus sp yang ditandai dengan terbentuknya koloni jamur yang lebih subur jika dibandingkan dengan media SDA, oleh karna itu peneliti ingin melakukan penelitian lanjutan tentang "Efektifitas berbagai variasi konsentrasi Bekatul terhadap Pertumbuhan Candida albicans".

Tujuan umum dalam penelitian ini adalah untuk mengetahui Efektifitas berbagai variasi konsentrasi Bekatul terhadap Pertumbuhan Candida albicans. Dan tujuan khusus dalam penelitian ini adalah untuk menentukan pada konsentrasi berapa pertumbuhan Candida albicans yang efektif.

\section{METODE}

Jenis penelitian yang digunakan adalah eksperimen laboratorik, yaitu untuk mengetahui sejauh mana efektifitas berbagai variasi konsentrasi bekatul terhadap pertumbuhan Candida albicans yang dilakukan di Balai Besar Laboratorium Kesehatan Makassar pada tanggal 5 Mei sampai 23 Mei 2019.

Populasi dalam penelitian ini adalah semua bekatul pada pabrik penggilingan padi di Kecamatan Kajuara, Kabupaten Bone. Sampel dalam penelitian ini adalah bekatul dengan besaran sampel 60 gram. Pengambilan sampel pada penelitian ini menggunakan teknik Probability Sampling dengan cara Simple Random Sampling yaitu pengambilan sampel dilakukan secara acak tanpa memperhatikan strata yang ada dalam populasi penelitian.

\section{Langkah-Langkah Penelitian}

Tahap pra analitik dilakukan dengan menyiapkan semua alat dan bahan yang akan digunakan dalam proses pembuatan media, serta alat dan bahan untuk inokulasi dan uji konfirmasi jamur Candida albicans.

Tahap analitik dimulai dengan pembuatan media bekatul dan media control, kemudian dilakukan penanaman Candida albicans pada semua media uji, dan diakhiri dengan uji konfirmasi pertumbuham Candida albicans menggunakan alat Vitek II.

Tahap pasca analitik dilakukan dengan pencatatan hasil penelitian dari alat Vitek II kemudian dilanjutkan dengan mendeskripsikan hasil dalam 
bentuk narasi.

\section{Pengolahan dan analisis data}

Adapun tekhnik analisa data pada penelitian ini menggunakan analisis deskriptif yang disajikan dalam bentuk tabel dan dibahas secara narasi.

\section{HASIL}

Hasil penelitian ini menunjukkan bahwa semakin tinggi konsentrasi bekatul maka semakin banyak jumlah koloni Candida albicans yang dihasilkan dibandingkan dengan media kontrol (SDA). Bekatul dapat digunakan sebgai media alternatif terhadap pertumbuhan Candida albicans pada konsentrasi minimal 5\%, perbedaan koloni Candida albicans pada media bekatul 5\% dan media kontrol (SDA) terlihat jelas baik dari jumlah maupun ukuran koloninya. Sedangkan konsentrasi media bekatul yang efektif didapatkan pada konsentrasi $10 \%$ sampai dengan $15 \%$ yaitu secara makroskopik hampir sama bahkan lebih dari koloni pada media SDA.

\section{PEMBAHASAN}

Untuk tumbuh dan berkembang, jamur membutuhkan nutrien dan berbagai faktor lingkungan yang sesuai. Nutrien berupa unsur atau senyawa kimia dari lingkungan digunakan sel sebagai konstituen kimia penyusun sel. Secara umum nutrien yang diperlukan dalam bentuk karbon, nitrogen, sulfur, fosfor, kalium, magnesium, natrium, kalsium, nutrien mikro (besi, mangan, zink, kobalt) dan vitamin. Salah satunya adalah bekatul yang memiliki kandungan nutrisi bagi kelangsungan hidup jamur, sehingga jamur Candida albicans dapat tumbuh subur pada media ini.

Vol. 11 No. 1, Juni 2020

DOI: https://doi.org/10.32382/mak.v11i1.1514
Semakin hari koloni jamur ini semakin membesar karena adanya pertambahan volume sel. Hal ini sesuai dengan pernyataan Gandjar, et al (2006) bahwa salah satu parameter pertumbuhan adalah pertambahan volume sel, hal ini dikarenakan adanya pertambahan protoplasma dan senyawa asam nukleat. Pertambahan volume sel tersebut adalah irreversibel, artinya tidak dapat kembali kevolume semula. Pada umumnya suatu koloni digunakan sebagai kriteria terjadinya pertumbuhan, karena massa sel tersebut berasal dari satu sel.

Dari hasil penelitian ini menunjukkan bahwa semakin tinggi konsentrasi bekatul maka semakin banyak jumlah koloni Candida albicans yang dihasilkan dibandingkan dengan media kontrol (SDA). Bekatul dapat digunakan sebgai media alternatif terhadap pertumbuhan Candida albicans pada konsentrasi minimal 5\%, perbedaan koloni Candida albicans pada media bekatul 5\% dan media kontrol (SDA) terlihat jelas baik dari jumlah maupun ukuran koloninya. Sedangkan konsentrasi media bekatul yang efektif didapatkan pada konsentrasi $10 \%$ sampai dengan $15 \%$ yaitu secara makroskopik hampir sama bahkan lebih dari koloni pada media SDA. Perbedaannya dapat dilihat pada lampiran 5.

Jadi semakin tinggi konsentrasi bekatul semakin banyak jumlah koloni yang terbentuk. Hal ini disebabkan karena pada konsentrasi tertinggi yaitu $15 \%$ kandungan karbohidrat dan protein pada media lebih tinggi dibandingkan dengan konsentrasi 5\%, dan 10\%, sehingga jamur Candida albicans memanfaatkan kandungan nutrisi pada media bekatul terutama karbohidrat dan protein untuk tumbuh dan berkembang. 
Hal ini menunjukkan bahwa kandungan nutrisi yang kompleks pada bekatul digunakan oleh Candida albicans untuk tumbuh dan berkembang. Salah satu kandungan nutrisi pada bekatul yang dimanfaatkan Candida albicans adalah karbohidrat dan protein. Karbohidrat dan derivatnya merupakan substrat utama untuk metabolisme karbon, jamur juga memiliki kemampuan menguraikan protein dilingkungannya dan menggunakannya sebagai sumber nitrogen maupun karbon. Selain itu, jamur juga membutuhkan nutrien dan faktor-faktor lingkungan yang sesuai untuk tumbuh dan berkembang. Nutrien berupa unsur-unsur atau senyawa kimia yang terkandung dalam bekatul digunakan sel sebagai konstituen kimia penyusun sel. Secara umum nutrien yang diperlukan dalam bentuk karbon, protein, nitrogen, oksigen dan sumber mineral. Karbon menempati posisi yang unik karena semua organisme hidup memiliki karbon sebagai salah satu senyawa pembangun tubuh.

Kandungan gizi bekatul tersusun dari beberapa zat, seperti air, protein, lemak, vitamin, mineral, serat dan karbohidrat. Berdasarkan analisis yang dilakukan oleh Sucofindo kandungan tersebut terdiri dari komponen sebagai berikut : air 2,49\%, protein $8,77 \%$, lemak $1,09 \%$, abu $1,60 \%$, serat $1,69 \%$, karbohidrat $84,36 \%$ dan kalori 382,32 kal (Nursalim dan Razali, 2007). Kandungan nutrisi pada media bekatul ini sangat kompleks dan kaya gizi sehingga dapat mempengaruhi pertumbuhan jamur Candida albicans ini baik itu jumlah koloni, ukuran, maupun kecepatan pertumbuhan.

Adapun kendala yang saya dapatkan selama proses penelitian ini adalah pasien dengan pemeriksaan
Candida albicans di Balai Besar Laboratrium Kesehatan Makassar saat itu sangat sedikit. Sehingga membuat penelitian ini tertunda selama dua bulan. Pada proses Persiapan sampel jamur, pemurnian biakan sampel Candida albicans dilakukan secara berulan-ulang, spesies yang didapatkan bervariasi dari Candida famata, Candida ciferii dan Candida albicans. Setelah didapatkan sampel dengan spesies Candida albicans barulah dilanjutkan pembiakan pada media bekatul dan media control (SDA).

\section{KESIMPULAN}

Berdasarkan penelitian yang telah dilakukan di Balai Besar Laboratorium Kesehatan Makassar dengan judul "Efektifitas Berbagai Variasi Konsentrasi Bekatul terhadap Pertumbuhan Candida albicans" dapat disimpulkan bahwa :

1. Bekatul dapat dimanfaatkan sebagai media pertumbuhan jamur Candida albicans yang ditandai dengan terbentuknya koloni jamur yang subur menyerupai media SDA.

2. Konsentrasi media bekatul yang efektif didapatkan pada konsentrasi $10 \%$ sampa dengan $15 \%$ yaitu secara makroskopik hampir sama bahkan lebih dari koloni pada media SDA, jadi semakin tinggi konsentrasi bekatul semakin banyak jumlah koloni yang terbentuk

\section{SARAN}

Saran dari hasil penelitian ini yaitu agar lebih memperhatikan kualitas bekatul yang digunakan, serta uji pertumbuhan jamur pada media bekatul dari spesies yang beragam. 


\section{UCAPAN TERIMA KASIH}

Kami mengucapkan banyak terimakasih kepada seluruh pihak yang membantu dalam penelesaian skripsi ini, terutama kepada kedua orang tua, seluruh civitas akademi jurusan Analis Kesehatan Poltekkes Kemenkes Makassar, dan kepada semua pihak yang tidak bias saya sebutkan satu persatu.

\section{DAFTAR PUSTAKA}

Aini. N., Rahayu. T. 2015. Media Alternatif untuk Pertumbuhan Jamur Menggunakan Sumber Karbohidrat yang Berbeda, (Online), (http://www.jurnal.fkip.uns.ac.id /, diakses 8 Januari 2019).

Anonim. 2012. Bekatul Makanan Tidak Elit yang Sangat Menyehatkan Tubuh (http://ydbp.ui.ac.id, diakses 8 Januari 2019).

Anonim. 2011.

(http://repository.usu.ac.id/, diakses 8 Januari 2019).

Bact/Alert.https://ekatalog.lkpp.go.id/ba ckend/produk/ download lampiran/33649. Diakses tanggal 13 Januari 2019

Brooks. G.F., Butel. J.S., Morse.S.A. 2005. Mikrobiologi Kedokteran (Medical

Microbiology). Jakarta: Salemba Medika.

Dewi. C., Purwoko. T., Pangastuti. A. 2005. Produksi Gula Reduksi oleh Rhizopus oryzae dari Substrat Bekatul, (online), Vol. 2, No. 1, (https://core.ac.uk/download/fil es/478/12345764.pdf, diakses 8 Januari 2016).

Dwidjoseputro. D. 2010. Dasar-Dasar Mikrobiologi. Jakarta: Penerbit Djambatan.
Entjang. I. 2003. Mikrobiologi dan Parasitologi. Bandung: PT. Citra Aditya Bakti.

Gandjar. I., Sjamsuridzal. W., Oetary. A 2006. Mikologi Dasar dan Terapan. Jakarta: Yayasan obor Indonesia.

Goldman. G.H., Osmani. S.A. 2008. The Aspergilli. Genomics, Medical Aspects, Biotechnology, and Research Methods. United Stated of America: CRP Press Taylor and Francis Group.

Hidayat. N., Padaga. M.c., Suhartini. S. 2006. Mikrobiologi Industri. Yogyakarta: Andi Offset.

Irianto. K. 2013. Parasitologi Medis. Bandung: enerbit Alfabeta.

Kalma., Herman., Naim. N., Bakhri. S. 2017. Panduan Penulisan Skripsi. Makassar: Kementerian Kesehatan RI Politeknik Kesehatan Makassar Jurusan Analis Kesehatan.

Muharram. A. F., Afiah. N. 2016. Penuntun Praktikum Mikologi. Makassar: Akademi Analis Kesehatan Muhammadiyah Makassar.

Nursalim. Y., Razali. Z.Y. 2007. Bekatul Makanan yang Menyehatkan. Jakarta: Agro Media Pustaka.

Safitri. R., Novel. S.S. 2010. Medium Analisis Mikroorganisme (Isolasi dan Kultur). Bandung: Penerbit buku kesehatan.

Suprihatin. S. D. 1982. Candida dan Kandidiasis pada Manusia. Jakarta: Fakultas Kedokteran Universitas Indonesia.

Tiyasningsih, W. 2010. Potensi Pakan sebagai Sumber Pencemaran Aspergillus sp Penyebab Aspergillosis pada Unggas, 
(Online),

(http://journal.unair.ac.id/ diakses 15 Januari 2019).

VITEK-2 Brosur. http://ce.am/en/products/vitekindustri1362. Diakses tanggal 13 Januari 2019

Widarti., Djasang. S., Dewi. N.U., Arwin. 2015. Mikologi Terapan.
Makassar:

Kesehatan RI Politeknik

Kesehatan

Wikipedia, 2018, Sabouraud Agar, https://en.wikipedia.org/wiki/

Sabouraud_agar, diakses 9 Februari 2019. 
Tabel 1. Hasil Penelitian

\begin{tabular}{|c|c|c|c|}
\hline \multirow{2}{*}{$\begin{array}{l}\text { Konsentrasi } \\
\text { Bekatul }\end{array}$} & \multicolumn{2}{|c|}{ Perlakuan } & \multirow{2}{*}{$\begin{array}{c}\text { Hasil } \\
\text { Identifikasi } \\
\text { Jamur }\end{array}$} \\
\hline & 1 & 2 & \\
\hline Konsetrasi $5 \%$ & $\begin{array}{c}\text { Terdapat } \\
\text { pertumbuhan koloni }\end{array}$ & $\begin{array}{c}\text { Terdapat } \\
\text { pertumbuhan koloni }\end{array}$ & $\begin{array}{l}\text { Candida } \\
\text { albicans }\end{array}$ \\
\hline Konsetrasi $10 \%$ & & & \\
\hline Konsetrasi $15 \%$ & $\begin{array}{l}\text { pertumbuhan koloni } \\
\text { jamur }\end{array}$ & $\begin{array}{c}\text { pertumbuhan koloni } \\
\text { jamur }\end{array}$ & albicans \\
\hline Kontrol + & $\begin{array}{c}\text { Terdapat } \\
\text { pertumbuhan koloni } \\
\text { jamur }\end{array}$ & $\begin{array}{l}\text { Terdapat pertu } \\
\text { mbuhan koloni } \\
\text { jamur }\end{array}$ & $\begin{array}{l}\text { Candida } \\
\text { albicans }\end{array}$ \\
\hline & $\begin{array}{c}\text { Terdapat } \\
\text { pertumbuhan koloni } \\
\text { jamur }\end{array}$ & $\begin{array}{c}\text { Terdapat } \\
\text { pertumbuhan koloni } \\
\text { jamur }\end{array}$ & $\begin{array}{l}\text { Candida } \\
\text { albicans }\end{array}$ \\
\hline
\end{tabular}

Gambar 1. Hasil pertumbuhan jamur pada media bekatul dan media kontrol (SDA)

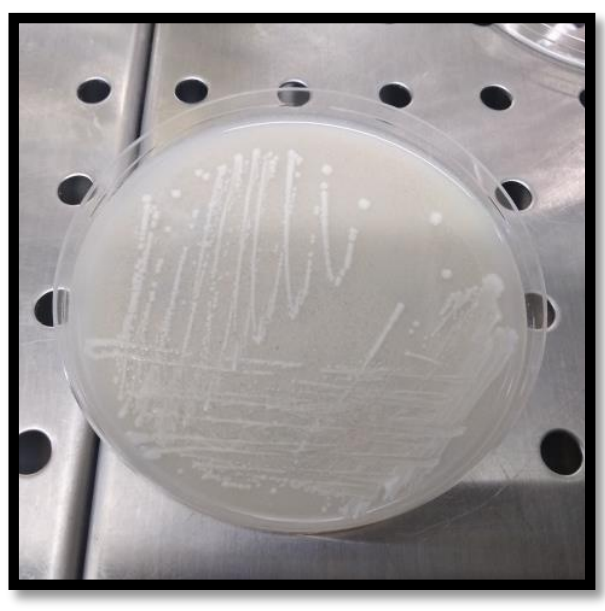

Bekatul konsentrasi 5\%

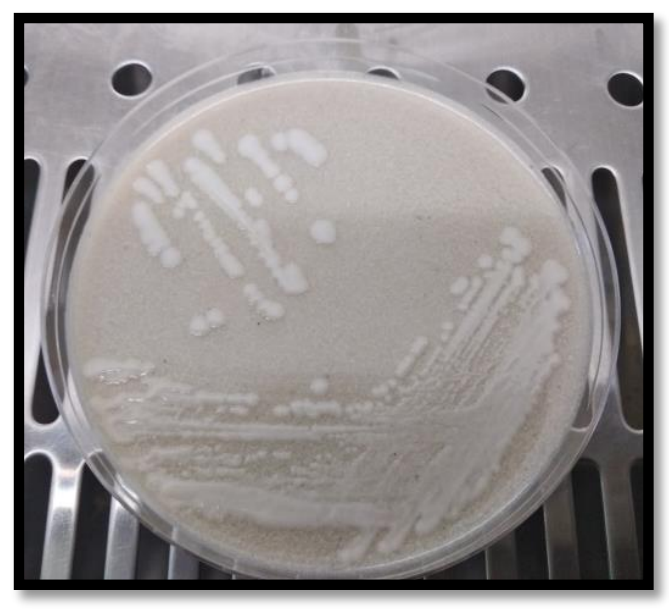

Al Bekatul konsentrasi 10\% 

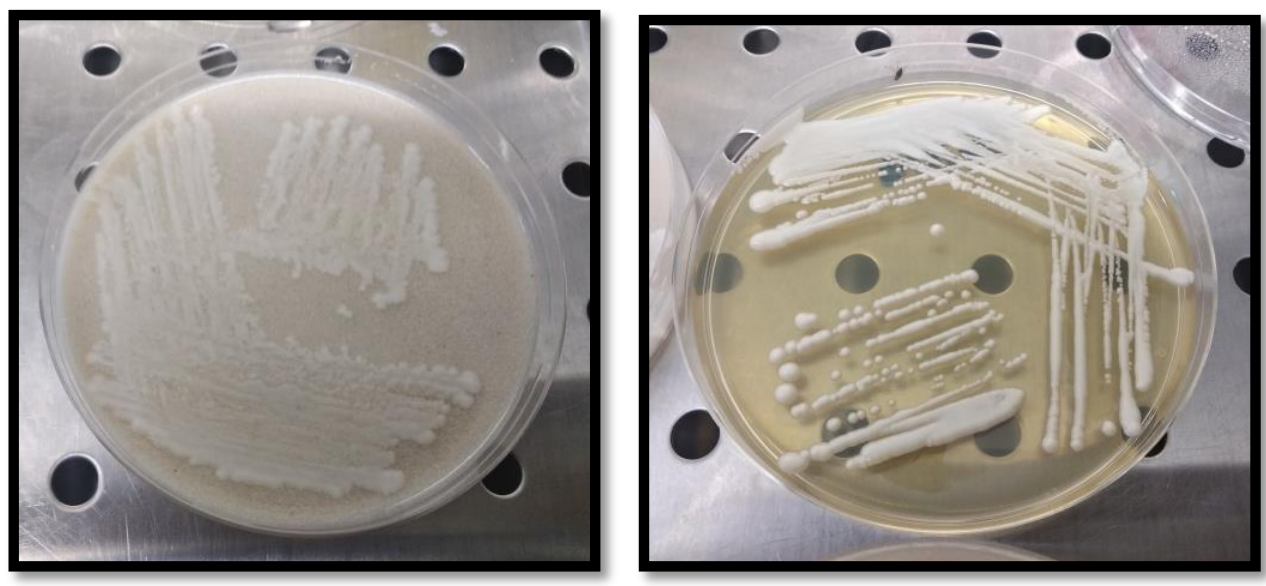

Bekatul konsentrasi 15\%

Media kontrol (SDA)

Vol. 11 No. 1, Juni 2020

DOI: https://doi.org/10.32382/mak.v11i1.1514 